\title{
ANALISIS KADAR MAGNESIUM, KALSIUM DAN KALIUM IBU HAMIL PREEKLAMSI HASIL INTERVENSI JEMUR SINAR MATAHARI
}

\author{
Siti Marfu'ah ${ }^{1 *}$, Nopri Padma Nudesti ${ }^{1}$ \\ 1STIKES Bakti Utama Pati \\ Email: marfuah_sty@yahoo.com*
}

Diterima : 8 Desember 2020 . Disetujui : 15 Juli 2021 . Dipublikasikan : 28 Juli 2021

\begin{abstract}
ABSTRAK
Kekurangan defisiensi gizi berperan dalam terjadinya preeklampsia. Pada ibu hamil dengan preeklamsi memiliki kecenderungan terjadinya penurunan terhadap kadar kalium, kalsium dan magnesium dibandingkan dengan ibu hamil normal. Tujuan dari penelitian ini adalah untuk mengetahui perbedaan perbedaan Kadar Magnesium, Kalsium Dan Kalium Ibu Hamil Preeklamsi setelah dilakukan Intervensi Jemur Sinar Matahari. Penelitian ini menggunakan desain penelitian quasy eksperimental dengan jenis ranangan penelitian one group pretest posttest. Penelitian dimulai dari melakukan identifikasi terhadap permasalahan ibu hamil dengan preeklamsi dimana ibu hamil yang mengalami preeklamsi terdapat keenderungan penurunan kadar mikronutrien dalam darah seperti magnesium, kalium dan kalsium. Setelah identifikasi merumuskan dan melakukan analisis masalah. Data penelitian dianalisis secara univariat dan bivariat dengan menggunakan uji statistik Uji Wilcoxson. Populasi dalam penelitian ini adalah seluruh ibu hamil preeklamsia yang pada saat penelitian sedang melakukan pemeriksaan di Puskesmas wilayah kabupaten Pati. Sampel dalam penelitian ini sejumlah 20 responden yang diperoleh melalui teknik sampling incidental sampling dengan teknik pengambilan sampel selama periode penelitian (consercutive sampling). Hasil penelitian diketahui bahwa ada terdapat perbedaan signifikan kadar kalium, kalsium dan magnesium ibu hamil sebelum dan sesudah dilakukan jemur matahari, hal ini menunjukkan bahwa intervensi jemur sinar matahari memberikan hasil yang cukup signifikan untuk meningkatkan kadar kalium, kalsium dan magnesium pada ibu hamil dengan pre eklamsi. Hal ini ditunjukkan dengan nilai $P$ value pre intervensi jemur matahari dan post intervensi jemur matahari untuk kalium, kalsium dan magnesium $<0,05$. ( $P$ Value Kadar kalium hasil intervensi 0,005 ; $P$ value Kadar Kalsium hasil intervensi 0,016; $P$ value kadar magnesium hasil intervensi 0,007).
\end{abstract}

Kata kunci $\quad$ : Preeklamsi, Magnesium, Kalium, Kalsium, Sinar Matahari

\section{ABSTRACT}

Malnutrition deficiency plays a role in the occurrence of preeclampsia. Pregnant women with preeclampsia have a tendency to decrease levels of potassium, calcium and magnesium compared to normal pregnant women. The purpose of this study was to determine the differences in levels of magnesium, calcium and potassium in pregnant women with preeclampsia after the sun drying intervention. This study used a quasi-experimental research design with one group pretest posttest type of research design. The study started from identifying the problems of pregnant women with preeclampsia where pregnant women who had preeclampsia had a tendency to decrease levels of micronutrients in the blood such as magnesium, potassium and calcium. After identification formulate and analyze the problem. The research data were analyzed univariately and bivariately using the Wilcoxson test statistical test. The population in this study were all preeclampsia pregnant women who at the time of the study were conducting an examination at the Pati district health center. The sample in this study was 20 respondents who were obtained through incidental sampling with a sampling technique during the research period (conservative sampling). The results showed that there were significant differences in the levels of potassium, calcium and magnesium in pregnant women before and after sun drying, this indicates that the sun drying intervention gave significant results to increase potassium, calcium and magnesium levels in pregnant women with pre-eclampsia. . This is indicated by the $P$ value of pre-intervention in the sun and post-intervention in the sun for potassium, calcium and magnesium $<0.05$. (P value of potassium level as a result of intervention is 0.005 ; $P$ value of calcium level as result of intervention is 0.016 ; $P$ value of magnesium level from intervention is 0.007 ).

Keywords: Preeclampsia, Magnesium, Potassium, Calcium, Sunlight

Analisis Kadar Magnesium, Kalsium Dan Kalium Ibu Hamil ...

(Siti Marfu'ah, Nopri Padma Nudesti) 


\section{PENDAHULUAN}

Angka Kematian lbu (AKI) merupakan salah satu indicator dalam menentukan derajat kesehatan perempuan. Banyak nya AKI pada era ini membuat masyarakat untuk menyadari betapa pentingnya untuk meningkatkan kesehatan ibu (Kemenkes RI, 2013).

Survey Demografi Kesehatan Indonesia (SDKI) pada tahun 2015 Angka Kematian Ibu (AKI) berjumlah 305/100.000 kelahiran hidup, angka tersebut menurun dibanding pada tahun 2012 dengan angka berjumlah 359/100.000 kelahiran hidup. Angka ini belum memenuhi target total MDGs (Millenium Development Goals) ke-5 tetapi sudah mengalami penurunan meskipun belum signifikan. Potensi untuk mencapai MDGs ke-5 guna menurunkan AKI diperlukan kesungguhan dan kerja keras dari berbagai sector. Kematian ibu di Indonesia masih di dominasi oleh tiga penyebab utama kematian ibu yaitu perdarahan, hipertensi dalam kehamilan (HDK), dan infeksi (Kemenkes Kesehatan RI. 2015).

Program Pembangunan Kesehatan diprioritaskan pada upaya peningkatan derajat kesehatan ibu dan anak, pada kelompok yang paling rentan kesehatannya yaitu ibu hamil, ibu bersalin dan bayi pada masa perinatal. Preeklampsia merupakan penyakit hipertensi, proteinuria dan edema yang terjadi karena kehamilan.

Beberapa studi dan penelitian, faktor mineral dan gizi berperan sebagai salah satu etiologi preeklampsia. Setalah digali secara mendalam, terdapat manfaat potensial yang didapatkan dari konsumsi suplemen kalsium selama kehamilan yang menurunkan preeklampsia. Perubahan pada fungsi vaskuler ternyata berperan penting dalam kontrol resistensi vaskuler dan tekanan darah. Selain itu, suplemen kalsium mencegah terjadinya hipertensi dalam kehamilan dengan cara menjaga kadar ion kalsium dalam rentang fisiologis yang sangat penting dalam sintesis substansi vasoaktif seperti prostasiklin dan nitric oxide pada endotel dalam mempertahakan fungsi endotel normal dan menurunkan tekanan darah (Adamova et al, 2009).

Selain Kalsium, konsumsi kalium dapat meningkatkan konsentrasinya didalam cairan intraseluler, sehingga terjadi kecenderungan menarik cairan dari bagian ekstraseluler dan menurunkan tekanan darah. Konsumsi kalium dalam juga dapat melindungi individu dari hipertensi.

Magnesium merupakan salah satu mineral yang berperan penting bagi kesehatan dan sistem metabolisme tubuh. Mineral ini ikut bekerja dalam sekitar 300 fungsi enzim pada proses reaksi kimia tubuh dengan berbagai bentuk. Proses sintesa protein, fungsi saraf dan otot, kontrol kadar glukosa darah dan juga pengontrol tekanan darah merupakan sebagian fungsi metabolisme tubuh yang berkaitan erat dengan magnesium. Berdasarkan hasil penelitian Hendri Devita tentang hubungan kadar magnesium dan kejadian preeklamsi pada ibu hamil trimester III di RSUP Dr. M.Djamil Pada Tahun 2015 diperoleh hasil ada hubungan kadar magnesium dengan kejadian preeklampsia. Magnesium menunjukkan peran besar dalam eklamsia untuk mencegah kejang berulang

Kekurangan defisiensi gizi berperan dalam terjadinya preeklampsia. Mineral kalsium dan magnesium selama ini diketahui dapat menurunkan tekanan darah. Mineral-mineral tersebut menghambat terjadinya konstriksi pembuluh darah yang menyebabkan penurunan resistensi perifer sehingga terjadi penurunan tekanan darah.

Mikronutrien seperti magnesium, kalium dan kalsium dalam darah dapat diserap seara optimal oleh tubuh bila terdapat pro vitamin $D$ yang membantu proses penyerapan. Provitamin $D$ diperoleh melalui sinar UV atau paparan sinar matahari. Berdasarkan latar belakang diatas penulis ingin mengetahui 
"adakah perbedaan Kadar Magnesium, Kalsium Dan Kalium Ibu Hamil Preeklamsi setelah dilakukan Intervensi Jemur Sinar Matahari”.

\section{METODE PENELITIAN}

Penelitian ini menggunakan desain penelitian quasy eksperimental dengan jenis rancangan penelitian pretest-posttes control group design, dimana peneliti melakukan penilaian pada satu kelompok intervensi yang diukur sebelum dan sesudah pemberian intervensi jemur sinar matahari dan kelompok pembanding (kontrol). Desain dalam penelitian ini bertujuan untuk mengidentifikasi pengaruh jemur sinar matahari terhadap kadar magnesium, kalium dan kalsium. Jenis rancangan digambarkan sebagai berikut :

$$
\begin{array}{|lll}
\hline 01 & \mathrm{X} & 02 \\
\hline
\end{array}
$$

Keterangan :

01 : penilaian kadar magnesium, kalium dan kalsium pada ibu hamil preeklamsi sebelum dilakukan terapi jemur sinar matahari

$X$ : Perlakuan dengan jemur sinar matahari selama 30 menit mulai jam 09.00 - 10.00 WIB dengan lama pelaksanaan 14 hari.

02 : penilaian kadar magnesium, kalium dan kalsium pada ibu hamil preeklamsi setelah dilakukan terapi jemur sinar matahari

Populasi dalam penelitian ini adalah seluruh ibu hamil preeklamsia yang pada saat penelitian

sedang melakukan pemeriksaan di Wilayah Puskesmas Kabupaten Pati. Sampel dalam penelitian ini sejumlah 20 responden yang diperoleh melalui teknik sampling incidental sampling dengan teknik pengambilan sampel selama periode penelitian (consercutive sampling). Variabel bebas (independen) dalam penelitian intervensi jemur sinar matahari dan Variabel terikat (dependent) dalam penelitian ini adalah kadar magnesium, kallium dan Kalsium.

Analisis univariat dilakukan untuk memperoleh gambaran tentang distribusi variable bebas dan variabel terikat dengan mengihitung distribusi frekuensi dan proporsinya untuk mengetahui karakteristik dan subyek penelitian. Analisis Bivariat digunakan untuk menguji pengaruh dari intervensi jemur sinar matahari terhadap kadar magnesium, kalium dan kalsium ibu hamil preeklamsi, uji statistik yang digunakan adalah Uji Wilcoxson karena digunakan untuk mengukur perbedaan 2 kelompok data berpasangan yaitu kadar magnesium, kalium dan kalsium ibu hamil preeklamsi sebelum dan setelah dilakukan intervensi jemur sinar matahari dengan berdistribusi data tidak normal.

\section{HASIL PENELITIAN DAN PEMBAHASAN}

\section{Analisis Univariat}

Tabel 1

Analisis deskriptif hasil pemeriksaan Kadar Kalium, Kalsium dan Magnesium pada Ibu hanil.

\begin{tabular}{|c|c|c|c|c|c|}
\hline \multirow{3}{*}{$\frac{\text { No }}{1}$} & Kategori Ibu Hamil & Deskriptif & Kadar Kalium & Kadar Kalsium & Kadar Magnesium \\
\hline & Ibu Hamil dengan & Mean & 3,5 & 8,4 & 1,4 \\
\hline & Pre eklamsi & Minimum & 3,0 & 7,8 & 1,0 \\
\hline & & Maksimum & 4,6 & 10,8 & 2,0 \\
\hline
\end{tabular}




\begin{tabular}{llllll}
\hline No & Kategori lbu Hamil & Deskriptif & Kadar Kalium & Kadar Kalsium & Kadar Magnesium \\
\hline 2 & Ibu Hamil dengan & Mean & 4,3 & 8,9 & 2,2 \\
& Pre eklamsi hasil & Minimum & 3,7 & 8,5 & 1,8 \\
& intervensi Jemur & Maksimum & 5,3 & 10,3 & 2,5 \\
& Sinar Matahari & & & & \\
\hline
\end{tabular}

Berdasarkan tabel 1 terdapat perbedaan ratarata kadar kalium, kalsium dan magnesium pada ibu hamil dengan pre eklamsi sebelum dan sesudah dilakukan intervensi jemur sinar matahari. Hal ini menunjukkan ibu hamil dengan pre eklamsi memiliki kadar kalium, kalsium dan magnesium yang lebih rendah dibandingkan dengan ibu hamil normal (tidak pre eklamsi).

Kalium adalah merupakan ion yang bermuatan positif dan terdapat didalam sel intraseluler. Ion ini secara normal dikonsumsi dan diekresi dalam jumlah yang seimbang yaitu $10 \%$ dari asupan harian dan diekresi dalam feses dan $90 \%$ dalam urine. Keterkaitan antara kalium dengan preeklamsia Pangeluaran air dari tubuh diatur oleh ginjal dan otak. Hipotalamus mengatur konsumsi garam didalam darah, dengan merangsang kelenjar pituari mengeluarkan hormone antidiuretika (ADH). Hormone antidiuretika dapat dikeluarkan bilamana volume darah atau tekanan darah rendah. ADH dapat merangsang ginjal dan menahan atau menyerap kembali air kedalam tubuh.

Almatsier(2010) bila terlalu banyak air keluar yang keluar dari tubuh, maka volume darah dan tekanan darah turun. Sel-sel ginjal mengeluarkan enzim rennin, dimana renin dapat mengaktifkan protein didalam darah yang dinamakan angiotensinogen ke dalam bentuk aktifnya angiotensin. Angiotensin akan mengecilkan diameter pembuluh darah sehingga tekanan darah akan naik. Angiotensin dapat mengatur pengeluaran hormone aldosteron dari kelenjar adrenalin. Aldosteron akan mempengaruhi ginjal untuk untuk menahan air dan natrium.
Akibatnya, bila dibutuhkan lebih banyak air, akan lebih sedikit air yang dikeluarkan dari tubuh dan tekanan darah akan naik kembali.

Konsumsi natrium yang berlebihan menyebabkan kosentrasi natrium didalam cairan ekstraseluler meningkat. Astawan (2003) untuk dapat menormalkannya cairan intraseluler ditarik keluar, sehingga volume cairan ekstraseluler meningkat. Peningkatan volume cairan ekstraseluler tersebut dapat menyebabkan meningkatnya volume darah. Konsumsi kalium dalam jumlah yang tinggi dapat melindungi individu dari hipertensi. Menurut Astawan (2003) cara kerja kalium adalah kebalikan dari natrium. Konsumsi kalium yang banyak akan menigkatkan kosentrasinya didalam intraseluler, sehingga cenderung menarik cairan dari ektra seluler dan menurunkan tekanan darah.

Seperti diketahui di beberapa penelitian, selain usia, paritas, dan riwayat preeklampsia di kehamilan sebelumnya sebagai faktor penyebab terjadinya preeklampsia terdapat pernyataan bahwa nutrisi berperan dalam kejadian preeklampsia. Terdapat penelitian yang menunjukkan bahwa asupan suplemen kalsium pada wanita dengan status kalsium rendah dapat menunjukkan efek perlindungan protektif dari kejadian preeklampsia. Data tersebut mendukung hipotesis bahwa asupan suplemen kalsium yang kurang selama kehamilan dapat meningkatkan insiden preeklampsia. Asupan rendah kalsium dapat menyebabkan peningkatan tekanan darah dengan merangsang hormon paratiroid atau pelepasan renin, peningkatan kalsium intraseluler yang terjadi di otot polos pembuluh darah sdapat menyebabkan 
vasokonstriksi. Dengan adanya pemberian suplementasi kalsium dapat mengurangi pelepasan paratiroid dan mengurangi kontraktilitas otot polos. Hal ini mengurangi kontraktilitas otot halus rahim atau meningkatkan kadar magnesium serum sehingga mencegah persalinan prematur dan melahirkan. Suplemen kalsium tampaknya mengurangi sekitar setengah risiko preeklampsia, kelahiran prematur, kematian, atau morbiditas serius, terutama pada wanita berisiko tinggi dengan asupan kalsium rendah sebelumnya (Dodd et al, 2014; Kanagal et al, 2014).

Magnesium memiliki peran yang cukup besar dalam eklamsia untuk mencegah kejang yang berulang. Cara pengobatan preeklampsia di Inggris beragam antar rumah sakit tetapi selalu diawali dengan pemberian intravena magnesium sulfat 4 gram (kira-kira 16 mmol Mg 2+) dalam 20 menit dilanjutkan dengan infuse intavena dengan kecepatan 1 gram (kira-kira 4 mmol Mg 2+) tiap jam. Magnesium dapat bekerja sebagai vasodilator serebral dan stabilisator membran, mengurangi iskemia dan kerusakan neuron yang mungkin terjadi. Obat ini bisa bekerja sebagai anti konvulsan sentral yang memblok reseptor $\mathrm{N}$ methyl-D-aspartat. Magnesium mempunyai jangkauan terapi yang luas dan monitoring klinis dengan melakukan observasi frekuensi pernapasan, saturasi PO2 (pulse oximetry) dan reflek perifer (Wiknjosastro, 2006).

Janin Ibu Hamil memerlukan 1 gram magnesium. Konsentrasi magnesium meningkat selama kehamilan dengan RDA $320 \mathrm{mg}$ dan 50\% dari magnesium diserap oleh ibu. Magnesium dibutuhkan oleh tubuh untuk mendukung pertumbuhan jaringan lunak (Kristiyanasari, 2010) Magnesium memiliki peranan penting dalam berbagai proses fungsi fisiologis didalam tubuh yaitu adanya proses pembekuan darah, bersama dengan natrium dan kalium dapat mempertahankan potensial membran sel, tranduksi sinyal antara reseptor hormon, eksitabilitas neuromuskuler, integritas membran sel, proses neurotransmisi, membentuk struktur tulang dan sebagai cadangan kalsium tubuh. Kadar magnesium dalam plasma ditentukan oleh absorbsi magnesium yang terjadi pada saluran cerna, resorbsi magnesium pada tulang dan pengeluaran magnesium melalui tinja, urin dan keringat (Widiyani, 2013)

\section{Analisis Bivariat}

Tabel 2 Analisis Kadar Kalium Kalium, kalsium dan magnesium pada ibu hamil normal dan Pre Eklamsi

\begin{tabular}{llll}
\hline & Kalium & Kalsium & Magnesium \\
\hline Wilcoxon W & 74,000 & 103,000 & 62,500 \\
Z & $-2,356$ &,- 153 & $-3,235$ \\
Asymp. Sig. (2-tailed) &, 018 &, 879 &, 001 \\
\hline
\end{tabular}

Berdasarkan tabel 2 Uji statistik yang Berikut hasil yang menunjukkan terdapat perbedaan digunakan untuk dua kelompok berpasangan pada 2 jenis pemeriksaan yang telah dilakukan yaitu menggunakan uji Wilcoxon. Berdasarkan hasil uji diperoleh bahwa terdapat perbedaan kadar kalium, kalsium dan magnesium pada ibu hamil normal dengan ibu hami pre eklamsi dengan nilai sig $<0,05$. pada kalium dan magnesium sedangkan tidak ada perbedaan yang signifikan pada kadar kalsium ibu hamil normal dengan ibu

hamil pre eklamsi. 
Tabel 3 Analisis Kadar Kalium Kalium, kalsium dan magnesium pada ibu pre eklamsi pre dan post intervensi jemur matahari.

\begin{tabular}{llll}
\hline & Post_Intervensi_Kalium & - Post_Intervensi_Kalsium & - Post_Intervensi_Magnesium - \\
& Pre_Intervensi_Kalium & Pre_Intervensi_Kalsium & Pre_Intervensi_Magnesium \\
\hline Z & $-2,809^{\mathrm{b}}$ & $-2,398^{\mathrm{b}}$ & $-2,719 \mathrm{~b}$ \\
Asymp. Sig. (2-tailed) &, 005 &, 016 &, 007 \\
\hline
\end{tabular}

Berdasarkan tabel 3 dengan menggunakan uji Wilcoxon menunjukkan bahwa ada perbedaan cukup signifikan untuk akdar kalium, kalsium dan magnesium pada ibu hamil pre eklamsi hasil intervensi jemur sinar matahari. Dari hasil penelitian ibu hamil pre eklamsi yang dilakukan intervensi jemur sinar matahari selama 30 menit pada pukul 09.00 - 10.00 WIB secara rutin selama 14 hari menunjukkan adanya peningkatan kadar kalium, kalsium dan magnesium. Peningkatan dar ini memiliki fungsi untuk menurunkan adanya resiko pre eklamsi seperti eklamsi pada ibu hamil terutama trimester III.

Tingkat kalsium total pada ibu menurun selama kehamilan. Penurunan kalsium total disebabkan oleh adanya penurunan albumin serum sehingga terjadi penurunan fraksi kalsium yang terikat oleh albumin. Namun kalsium yang terionisasi serum dapat konstan dan dapat juga menurun. Kebutuhan kalsium janin terpenuhi terutama melalui peningkatan penyerapan kalsium usus. Kalsium diserap melalui usus halus, dan penyerapannya berlipat ganda saat kehamilan 12 minggu, dengan penyerapan maksimal pada trimester ketiga.

Peningkatan penyerapan awal memungkinkan tulang ibu untuk dapat menyimpan kalsium sebelum tuntutan kebutuhan kalsium janin di trimester ketiga. Meskipun sebagian besar kebutuhan kalsium janin dapat dipenuhi oleh peningkatan penyerapan kalsium. Sebuah teori menyatakan bahwa ketika kadar kalsium serum menurun, maka tingkat kalsium intraseluler meningkat, sehingga dapat menyebabkan penyempitan otot halus di pembuluh darah sehingga meningkatkan resistensi vaskular sehingga dapat menyebabkan tekanan darah sistolik dan diastolik meningkat. Kadar kalsium serum yang rendah dapat meningkatkan tekanan darah dengan merangsang hormon paratiroid dan pelepasan renin sehingga kalsium intraseluler dapat meningkat didalam otot polos sehingga menyebabkan vasokontriksi pada pembuluh darah.

Peran suplementasi kalsium dalam mencegah preeklampsia adalah dengan mencegah penurunan kadar kalsium serum sehingga konsentrasi kalsium intraseluler mengalami penurunan, yang akan mengurangi kontraktilitas otot halus dan merangsang terjadinya vasodilatasi Sinar matahari merupakan sumber utama vitamin D yang paling baik. Sinar UVB yang berasal dari matahari akan diserap oleh kulit dan kemudian mengubah 7-dehidrokolesterol di kulit menjadi previtamin D3 yang selanjutnya secara spontan dikonversikan menjadi vitamin D3 (kolekasiferol). Vitamin D ini mengalami hidrolisis,hidrolisis yang pertama terjadi dalam hati dalam bentuk 25 (OH)D selanjutnya hidrolisisyang kedua terjadi di dalam dan diluar ginjal dalam bentuk 1,25 (OH)2D. Intensitas sinarUVB pada waktu antara 1 jam sebelum dan 1 jam setelah tengah hari mencapai nilaitertinggi dalam satu hari. Intesitas sinar matahari UVB adalah rendah pada pukul 07.00 pagi,meningkat pada jam-jam berikutnya sampai dengan pukul 11.00. Setelah pukul 11.00intensitas ini akan semakin relatif stabil dan tinggi sampai dengan pukul 14.00 untukkemudian menurun pada pukul 16.00 yang intensitasnya sama dengan pukul 07.00 denganwaktu 
pajanan yang dibutuhkan selama 15 menit.Sintesis vitamin $D$ juga tergantung dari tipe kulit, tipe kulit memengaruhi keadaanmelamin.

Menurut Fitzpatrick, Clasification Skin Scale penduduk Indonesia adalah tipe kulitIV. Tipe kulit IV adalah jenis kulit selalu menjadi coklat tapi tak pernah terbakar karenalebih banyak mengandung melanin, berbeda dengan tipe kulit III sering menjadi coklat kadang-kadang kulit terbakar. Melanin bersifat sebagai tabir surya alami yang dapatmemengaruhi penyerapan sinar matahari, sehingga hal ini dapat menurunkan efisiensi darifotosintesis prekolekasiferol (previtamin D3). Faktor lain yang juga berkontribusi dalamsintesis vitamin $\mathrm{D}$ adalah kecukupan akan asupan vitamin $\mathrm{D}$. Asupan ini dapat dipengaruhioleh pola makan sebelum dilakukan pemeriksaan kadar vitamin $\mathrm{D}$.

\section{SIMPULAN DAN SARAN}

Berdasarkan hasil analisis pemeriksaan laboratorium pada ibu hamil tentang kadar kalium, kalsium dan magnesium pada ibu hamil pre eklamsi hasil intervensi jemur sinar matahari dapat diambil kesimpulan bahwa terdapat pengaruh intervensi jemur sinar matahari terhadap peningkatan kadar kalium, kalsium dan magnesium pada ibu hamil pre eklamsi dengan nilai $P$ value $<0,05$. ( $P$ Value Kadar kalium hasil intervensi 0,$005 ; P$ value Kadar Kalsium hasil intervensi 0,016 ; $P$ value kadar magnesium hasil intervensi 0,007)

Petugas kesehatan khusus nya bidan dapat memberikan edukasi kepada ibu hamil untuk memanfaatkan sinar matahari sebagai intervensi guna meningkatkan kadar elektrolit dalam tubuh ibu hamil sehingga menurunkan resiko terjadinya pre eklamsi

Adanya pengembangan penelitian tentang tindaklanjut dari intervensi jemur matahari untuk meningkatkan kadar elektrolit kalium, kalsium dan magnesium bagi ibu hamil.

\section{DAFTAR PUSTAKA}

Adamova Z, Sifa O, Raouf AK. 2009. Vascular and cellular calcium in normal hypertensive pregnancy. Current Clinical Pharmacology. 4(3): 172-90.

Almatsier, Sunita. (2010). Prinsip dasar ilmu gizi. Jakarta: Gramedia Pustaka Utama.

Appel L, Brands M, Daniels S, Karanja N, Elmer P, Sacks F. Dietary Approaches to Prevent and Treat Hypertension. http://www.hypertensionha.org. Published 2006. Accessed Agust 13, 2019.

Artathi Eka Suryandari1, Lina Dwi Puji Rahayu; Pengaruh Defisiensi Kalium Saat Dengan Kejadian. Preeklamsia Di Rsu Harapan Ibu Purbalingga Tahun 2013

Astawan, M. 2009. Sehat dengan Hidangan Kacang dan Biji-Bijian. Depok: Penerbit Swadaya.

Cunningham F, Gary. 2009: Obstetri Williams. Jakarta; EGC.

Dodd JM, Cecilia OB, Rosalie MG. 2014. Preventing preeclampsia-are dietary factors the key?. BMC Medicine. 12:176.

Ekadewi Retnosari dkk. 2015. Korelasi antara Kadar Vitamin D dengan Kejadian Preeklamsi. IJEMC, Volume 2 No. 5, Desember 2015.

Ella Febriana, M. Zen Rahfiludin, Dina Rahayuning P. 2017. Hubungan Asupan Natrium, Kalsium dan Magnesium dengan Tekanan Darah pada lbu Hamil Trimester II dan III (Studi di Wilayah Kerja Puskesmas Bulu Kabupaten Temanggung). JURNAL KESEHATAN MASYARAKAT (eJournal) Volume 5, Nomor 4, Oktober 2017 (ISSN: 2356-3346).

Hendri Devita1, Vitri Yuli Afni Amran1 Hubungan Kadar Magnesium dengan Kejadian Preeklamsi pada Ibu Hamil Trimester III di RSUP Dr. M. Djamil Padang Tahun 2015 Jurnal Kesehatan Masyarakat Andalas diterbitkan oleh: Program Studi S-1 Kesehatan Masyarakat Fakultas Kesehatan Masyarakat Universitas Andalas. pISSN 1978-3833 e-ISSN 2442-6725 Volume10(2) 136-139 (2016)

Houstan, Marck $C$ et al. 2008. Potassium, Magnesium, and Calcium: Their Role in Both the Cause and 
Treatment of Hypertension. The Journal Of Clinical Hypertension.

Jeong, Hye Yun et al. 2017. Vitamin D and Hypertension. The Korean Society of Electrolyte Metabolism.

Kanagal DV, Rajesh A, Rao Kavyarashmi, Devi UH, Shetty H, Kumari S et al. 2014. Levels serum calcium and magnesium in preeclamptic and normal pregnancy: a study from Coastal India. $\mathrm{J}$ of Clinical and diagnostic research. 8(7): OC01OC04. Preeklampsia. Majority Vol 7 Nomor 3

Kristiyanasari, Weni. 2010. Gizi Ibu Hamil. Yogyakarta. Nuha Medika.

Kristiyanasari, Weni. Gizi lbu Hamil. Yogyakarta. Nuha Medika. 2010.

Purswani, Juhi M. 2017. The role of vitamin D in preeclampsia: a systematic review. BMC Pregnancy and Childbirth Journal. Preeklamsi. IJEMC, Volume 2 No. 5, Desember 2015.

Rendika Oktavia W. 2018. Suplementasi Kalsium selama Kehamilan sebagai Pencegahan Kejadian Pre eklamsi.

Rendika Oktavia Widiastuti, Hubungan Konsumsi
Suplemen Kalsium Yang Kurang Selama Kehamilan Sebagai Risiko Kejadian Preeklampsia Di Rumah Sakit Umum Daerah (Rsud) Kota Agung Kabupaten Tanggamus. Skripsi. Fakultas Kedokteran Universitas Lampung 2018

Rendika Oktavia Widiastuti. 2018. Hubungan Konsumsi Suplemen Kalsium Yang Kurang Selama Kehamilan Sebagai Risiko Kejadian Preeklampsia Di Rumah Sakit Umum Daerah (Rsud) Kota Agung Kabupaten Tanggamus. Skripsi. Fakultas Kedokteran Universitas Lampung.

Waryana.2010. Gizi Reproduksi. Yogyakarta; Pustaka Rihama.

Widiyani, Rosmha: Ibu Hamil Jangan Sampai Kekurangan Mikronutrien. Diakses pada tanggal (20 November 2020) di http:/l www.health.kompas.com/read

Wiknjosastro, Hanifa. 2009. IImu Kebidanan. Jakarta; Yayasan Bina Pustaka Sarwono

Wiknjosastro, Hanifa: Ilmu Kebidanan. Jakarta; Yayasan Bina Pustaka Sarwono Prawirohardjo. 2006 